\title{
Getting the story straight: Kierkegaard, MacIntyre and some problems with narrative
}

\author{
JOHN LIPPITT
}

University of Hertfordshire, $U K$

\begin{abstract}
As part of the widespread turn to narrative in contemporary
philosophy, several commentators have recently attempted to sign Kierkegaard up for the narrative cause, most notably in John Davenport and Anthony Rudd's recent collection Kierkegaard After MacIntyre: Essays on Freedom, Narrative and Virtue. In the context of this debate, I argue that the aesthetic and ethical existence-spheres in Either-Or cannot adequately be distinguished in terms of the MacIntyre-inspired notion of "narrative unity". Judge William's argument for the ethical life contains far more in the way of substantive normative content than can be encapsulated by the idea of "narrative unity", and the related idea that narratives confer intelligibility will not enable us to distinguish Kierkegaardian aesthetes from Kierkegaardian ethicists. "MacIntyrean Kierkegaardians" also take insufficient notice of further problems with MacIntyre's talk of "narrative unity", such as his failure to distinguish between literary narratives and the "enacted dramatic narratives" of which he claims our lives consist; the lack of clarity in the idea of a "whole life"; and the threat of self-deception. Finally, against the connections that have been drawn between
\end{abstract} Kierkegaardian choice and Harry Frankfurt's work on volitional identification, I

Correspondence Address: Dr John Lippitt, Philosophy, School of Humanities, University of Hertfordshire, de Havilland Campus, Hatfield, Herts, AL10 9AB, UK. E-mail: j.a.lippitt@herts.ac.uk 
show something of the dangers involved in putting too much stress on unity and wholeheartedness.

It has become increasingly common to suggest that we should understand various aspects of human life in terms of narrative. Narratives play a central role in human lives, from the education of children to the ways, according to many, in which adults attempt to understand their world and make sense of their lives. Various narrative conceptions of the self have been advanced, such as Alasdair MacIntyre's famous claim that the unity of the self "resides in the unity of a narrative which links birth to life to death as narrative beginning to middle to end". ${ }^{1}$ But it is far from clear exactly what claims about narrative made within different areas of philosophy and other disciplines amount to. It is especially unclear whether those who employ the term are using it in remotely the same way.

Recently, several commentators have attempted to sign Kierkegaard up for the narrative cause. In the introduction to their fascinating collection of essays Kierkegaard After MacIntyre: Essays on Freedom, Narrative and Virtue, John Davenport and Anthony Rudd describe MacIntyre's attempt at “understanding... human life in narrative terms" as "particularly Kierkegaardian". ${ }^{2}$ There are good prima facie reasons to connect Kierkegaard and narrative, from his interest in and use of parables and biblical narratives ${ }^{3}$ to the fact that several of his best-known works, such as Either-Or and Stages on Life's Way, somewhat resemble novels. Moreover, part of the interpretative task of approaching a Kierkegaardian pseudonym involves engaging with that pseudonym's life-view, an experience not unlike engaging with a 
literary character. In these and other ways, Kierkegaard appears to be a friend of narrative.

However, I have grave reservations about one key connection that has recently been made between Kierkegaard and narrative: the attempted use of the MacIntyre-inspired idea of "narrative unity" and related notions to distinguish the aesthetic and ethical spheres of life in Either-Or. In investigating this, I shall argue that the term "narrative" is simply not up to the task required of it by a number of commentators, such as Anthony Rudd. Rudd claims that Judge William's argument for the ethical life in Either-Or can be understood in terms of MacIntyrean "narrative unity". In section I, I consider Rudd's case. I argue that Judge William's argument in fact contains far more in the way of substantive normative content than can be encapsulated in the idea of "narrative unity", and that the MacIntyrean idea that narratives confer intelligibility will not enable us to distinguish a Kierkegaardian aesthete from a Kierkegaardian ethicist. In section II, I argue that once we investigate more closely MacIntyre's use of the notion of narrative, we shall see that there are further problems in store for a MacIntyre-inspired defence of the idea of "narrative unity". These include problems arising from MacIntyre's failure to distinguish between literary narratives and the "enacted dramatic narratives" of which he claims our lives consist; the unclarity of the idea of a "whole life"; and the threat of self-deception. Finally, in section III, I turn from problems with understanding the notion of "narrative unity" itself to a consideration of the wider question of whether unity and harmony really are as desirable in a human life as many suppose. In doing so, I focus on the connections John Davenport has drawn between Kierkegaardian choice and Harry Frankfurt's work on volitional identification. In criticising Frankfurt and Davenport, I take up a 
suggestion by Philip Quinn, who points out the potential for psychological oversimplification in self-understanding that attends a stress on unity and harmony. In aiming to continue Quinn's line of thought, I draw on work by Martha Nussbaum, amongst others.

\section{Narrative and Judge William's case for the ethical}

In their introduction to Kierkegaard After MacIntyre Davenport and Rudd say that they "discern a convergence towards a new consensus on what Kierkegaard meant by authentic 'self-choice' in Either/Or, and on the way in which Kierkegaard conceives of ethical selfhood generally". ${ }^{4}$ One key dimension of this is that Kierkegaard's "understanding of the development of ethical personality involves a quest for narrative unity". 5 Of all the contributors to the volume, the commentator who gives the most clearly central role to the notion of "narrative unity" or "narrative structure" in his account of Either-Or is probably Anthony Rudd, so it is this aspect of Rudd's argument that I shall consider here.

Rudd argues that Kierkegaard's aim is to show "how a rational appeal might be made to the disengaged or ironic modern self ... to reengage with tradition". ${ }^{6}$ He claims that the argument for the ethical life in Either-Or is effectively the same as MacIntyre's argument for his narrative conception of the self in chapter 15 of After Virtue. ${ }^{7}$ If true, this would be ironic, given MacIntyre's infamous objection to Kierkegaard in that text. MacIntyre presents the Kierkegaard of Either-Or as an irrationalist: as claiming that the only justification for the move from the aesthetic sphere of existence (represented by the rootless young man A) to the ethical sphere (represented by Judge 
William) is criterionless choice. On MacIntyre's story, Kierkegaard is a critical figure in the breakdown of "the Enlightenment's attempt to discover an independent rational justification for morality", and Either-Or is "a book which is at once the outcome and the epitaph"» of this attempt. This reading of Kierkegaard as an irrationalist has rightly received numerous rebuttals from Kierkegaard scholars, but according to several such commentators, Kierkegaard could be more of an ally for MacIntyre's project than the latter realises. ${ }^{9}$ Rudd glosses his claim that A's life constitutes “despair" because it has "no principle of unity" in MacIntyrean terms: A's, he tells us, is "a life which lacks a narrative structure". ${ }^{10}$

What should we say about this appeal to notions such as "narrative structure" and "narrative unity" to try to explain the argument of Either-Or? A large part of the problem with talk of "narrative" in general is the variety of ways in which the term gets defined (when it is defined at all). ${ }^{11}$ In light of these varying uses of the term, contributors to the "Kierkegaard after MacIntyre" debate need to be clearer about what they mean when they use it. ${ }^{12}$ Several write as if MacIntyre's use of the term was clear and uncontentious but - as I shall argue in section II - it is not. In addition, in order for the debate about narrative to be of much interest at all, I take it that the term must be used in a non-trivial manner. As Galen Strawson puts it, "if someone says ... that making coffee is a narrative ... because you have to think ahead, do things in the right order, and so on, and that everyday life involves many such narratives, then I take it that the claim is trivial."13

What could be meant, then, by the "narrative structure" of a life? Consider Rudd's claim in more detail: 
For the ethicist, life has meaning because it is directed towards the achievement of goals, which themselves lead on in intelligible ways to further projects at which she may succeed or fail. To understand any action is to situate it in a context which renders it intelligible, and that context is itself rendered intelligible by the wider narrative of the agent's life to which it contributes. Our lives make sense to us as long as we can tell ourselves an intelligible story about who we are and what we are doing. To lack such a narrative structure in one's life is to lack any stable sense of personal identity, any sense of oneself as enduring through time as the same person, as one who can be the bearer of obligations and entitlements. The aesthete's life reduces to a series of moments, pleasurable or unpleasurable, but with no principle of unity discernable in them. Furthermore, the ethicist recognises that the projects and commitments which define her identity are themselves socially defined, and require engagement with - though not uncritical acceptance of the traditions which give that society its sense of identity and coherence, which define what is characteristic about its way of life. ${ }^{14}$

At this point, I should add an important note of clarification. In what follows, I shall understand the term "aesthete", as do both Rudd and Davenport, as the default position for anyone who has not embraced the ethical or any higher Kierkegaardian existence-sphere (some form of the religious). ${ }^{15}$ This is important for two reasons. First, it reminds us that there is, in Davenport's words, "no Archimedean point outside" 16 the existence-spheres. But second - a point often overlooked, but to which I shall return later in this section - it means that we cannot dismiss the aesthetic life in general on the basis of the particularities of A. Most commentators would 
acknowledge that there is more to aestheticism than is embodied in the rootless young man of whose writings the bulk of the first volume of Either-Or consists. The varieties of the aesthetic life discussed in that volume range from the "immediate" raw sensuousness of Mozart's Don Giovanni to the reflective manipulator Johannes, the author of the "Seducer's Diary". As we shall see later in this section, Judge William also considers lives devoted to wealth, glory, nobility or the development of an exceptional talent to be varieties of aestheticism. Yet despite all this, commentators sometimes proceed as if A's occasional acknowledgment of his own despair suffices as a refutation of the aesthetic life in general. This conclusion is far too hasty.

Returning to the above quote from Rudd, note its focus on intelligibility. For Rudd, it seems that a key function of any narrative is to make something more intelligible. (This could be a way of distinguishing a narrative from a mere chronicle of events.) Perhaps one could argue, therefore, that "life narratives" are attempts to make our lives more intelligible.

Now, this focus on intelligibility is very much in the spirit of MacIntyre, who argues that the concept of an intelligible action is a more fundamental concept than that of an action as such (unintelligible actions being "failed candidates for the status of intelligible action". ${ }^{17}$ ) MacIntyre's general point is that agents and actions cannot be understood atomistically. For me to understand your actions and intentions, I must locate them in a temporal and social context, rather than viewing them as unconnected, isolated events. An apparently unintelligible action can become intelligible by "finding its place in a narrative". ${ }^{18}$ MacIntyre's memorable example of this is a young man who approaches a stranger at a bus stop and says: "The name of 
the common wild duck is Histrionicus histrionicus histrionicus". This apparently unintelligible action - the sentence itself is perfectly intelligible, but what was the young man's purpose in uttering it? - becomes intelligible once we realise that he has mistaken the stranger for someone who approached him in the library earlier and asked him if by chance he knew the Latin name of the common wild duck. Or that he has just come from a session with his psychotherapist, who is trying to remedy his shyness by encouraging him to talk to strangers ("But what shall I say?" "Oh, anything at all.,"19)

I have no real quarrel with MacIntyre's basic point here. But in the context of EitherOr, the introduction of intelligibility is problematic. For rather few of us cannot tell ourselves an intelligible story about who we are and what we are doing. Granted, there are occasions in life when we ask ourselves what the point is of that to which we have devoted our time: those occasions on which, to a certain kind of person, questions about the very purpose or "meaning" of one's life may occur. But even in such moments - which are relatively rare - intelligibility is not the issue. When my wife has left me, my teenage daughter has told me she'll never speak to me again, and I have lost my job, all in the same week, I might well face despair in a more everyday sense than Kierkegaard's. But even in such circumstances, I would be able to offer a perfectly intelligible narrative about why I married this woman; why I intervened to try and discourage my daughter from dating that Neanderthal suspected drug-pusher; why I took that job despite my knowledge of its insecurity. Intelligibility is not the problem. The point that matters in the Kierkegaardian context is that the concept of intelligibility will certainly not enable us to distinguish aesthetes from ethicists. As mentioned, Judge William discusses various aesthetes whose lives are devoted to 
wealth, glory, nobility or the development of a talent. Whatever the shortcomings of such lives, the issue is not that they are unintelligible. If we are to condemn such figures, it will have to be on some quite different basis to this. Yet, pace Rudd, this is precisely what Judge William does. For instance, consider the contrast the Judge draws between the aesthetic view of talent as something accidental (which distinguishes the person who has it from the person who hasn't), and the ethical view of talent as a calling (something everyone has, according to the Judge, and which therefore does not distinguish the brilliant pianist from any other human being in any fundamental sense $\left.{ }^{20}\right)^{21}$

Overall, my claim is that Judge William's argument contains far more in the way of substantive normative claims than can be boiled down to talk of the "narrative structure" or "narrative unity" of a life. It is certainly true that central to it is an insistence on the need for commitment to what Rudd calls "projects", but there is far more. First and foremost is the Judge's belief in God. He does at one point claim that "what is important in choosing is not so much to choose the right thing as the energy, the earnestness and the pathos with which one chooses", ${ }^{22}$ but he prefaces this with the words "if you are to understand me properly", and insists that "even though a person chose the wrong thing, he nevertheless by virtue of the energy with which he chose, will discover that he chose the wrong thing", 23 since the inwardness of choice is such that the chooser is brought into contact with "the eternal power that omnipresently pervades all existence". ${ }^{24}$ In other words, choose wrongly, and God will show you that you are wrong. This is hardly an uncontroversial claim. Yet it is but one of a range of substantive normative claims that the Judge makes. Others include that choosing oneself involves "receiving" or "accepting" oneself (thus 
distinguishing his view of choice from that of Sartre, a point MacIntyre seems to overlook in After Virtue); that choosing oneself "absolutely" involves recognition of one's guilt and need for repentance ${ }^{25}$ and that it is everyone's duty to marry ${ }^{26}$ and to work for a living. ${ }^{27}$ (Marriage, he also tells us, belongs properly to Christianity: pagans and Jews have failed to "perfect" it. ${ }^{28}$ )

All of this is part of the argument of part II of Either-Or. The Judge's accounts of receptivity, guilt and repentance are just as important a part of his argument as the case for choice and commitment. Any description of the argument in terms of an apparently neutral term like narrative, therefore, will underdescribe his extremely complex and contentious argument. To be fair to Rudd, he does recognise that for the Judge, ethical agency is rooted in the concrete life of a society. But as Rick Furtak has recently pointed out, on this view moral perception "takes place within a coherent system of ethical beliefs which define what is right and what is good". ${ }^{29}$ How, then, can it appeal to the disengaged or ironic modern self" who "stands outside all traditions"'? ${ }^{30}$ What is his incentive to respond to the Judge's plea to enter the water of bourgeois Christian marital domestic satisfaction?

Rudd's answer is something like this. Kierkegaard, he claims, holds that "we share a desire for our lives to be coherent narratives, and it is the failure of the aesthetic to meet that desire which makes it rational to prefer the ethical to it". ${ }^{31} \mathrm{He}$ further claims that the aesthete's despair inheres in the lack of continuity in his life. ${ }^{32}$ But this doesn't answer the question about why we should value a life of dutiful work and conventional marriage over other possible manifestations of the ethical life. (After all, despair can arise within a marriage or career too.) Moreover, this will not demarcate 
the aesthete from the ethicist, for at least two reasons. First, we need to understand the significance of the fact that A is actually a rather sophisticated kind of aesthete. Judge William recognises that there are great differences between individuals in the aesthetic sphere, ${ }^{33}$ and as we have noted, describes a variety of aesthetic lives that he clearly views as less sophisticated than A's. Those lives devoted to wealth, glory, nobility and the development of a special talent all count as aesthetic, and yet the Judge explicitly says that such views of life all have "a certain unity, a certain coherence". ${ }^{34}$ They also, we might add, possess a certain continuity, insofar as they pursue a goal. It can't, therefore, be accurate to attempt to distinguish the aesthetic from the ethical in terms of unity or coherence per se. ${ }^{35}$ Second, as noted, boredom and despair might be precisely what results from the rather conventional life Judge William recommends. One suspects that A would "see through" this, and as Furtak argues, his failure to hold back from moral engagement need not necessarily be seen as a failure to "'grow up' and realise the universal”, but might stem from "a lofty conception of human dignity" that will not rest satisfied with the Judge's proposed solutions. ${ }^{36}$ Furtak calls A's desire for something different from the appropriation of accepted conventions "the virtue of the romantic imagination", adding that if the aesthete "is to be denounced for his inability to form relationships, he should also be praised for criticizing his contemporaries in Socratic fashion, for caring about the wrong things." ${ }^{37}$ As we have noted, Judge William's justification of the conventional values that underlie his own life are hardly going to satisfy A. So as Furtak suggests, perhaps A is "hindered not by a resistance to actuality as such, but by doubts about the values of a particular civilization", 38 
Rudd later seems to acknowledge this problem. He says that "someone with the disconcerting brilliance, radicalism, and individuality of ' $A$ ' will not be able to find fulfilment in the enlightened but still rather blandly conventional morality preached by the Judge" ${ }^{39}$ But he does not seem to see what damage this does to this part of his argument. Once this is admitted, in what sense has the Judge gone beyond A? To be sure, the Judge's recognition of the need for commitment in life is an important insight. But one suspects that A too has an important insight: that the Judge does not provide sufficient reasons for why we should commit to what he commits to, that in important respects he mistakes the local for the universal. How - without begging the question - are we to decide which of these insights trumps the other? Rudd compares this case with one in which rival scientific theories can both "give an account of what they see that is formally consistent with their theoretical principles, but [where] one of these accounts may be very strained, over-complex, and depend on a mass of ad hoc auxiliary hypotheses, while the other is simple, straightforward, and fits easily with the rest of the theory". ${ }^{40}$ But this comparison will not do, as it fails to give due credit to the significance of the insight we can reasonably suppose someone with A's intelligence to have into the weak points in the Judge's case.

Kierkegaard himself was clearly aware of these weaknesses. Indeed, an early critic of Judge William was Johannes Climacus, the pseudonymous author of Kierkegaard's Philosophical Fragments and Concluding Unscientific Postscript. Climacus argues that the Judge's account of despair reveals that he fails to take on board how radical is the human dependence upon God. As Climacus puts it: "In despairing I use myself to despair, and therefore I can indeed despair of everything by myself, but if I do this I cannot come back by myself. It is in this moment of decision that the individual needs 
divine assistance". ${ }^{41}$ Alastair Hannay glosses this as follows: "properly to despair is to give up the idea of there being any human platform from which, or any procedure whereby, to establish one's kinship in thought and action with God". ${ }^{2}$

Relatedly, several commentators have also argued that the Judge also has an inadequate understanding of sin and repentance. Robert L. Perkins, for example, notes that the Judge operates without a sense that the awareness of the need for repentance is brought about by divine grace, ${ }^{43}$ and that his understanding of repentance is thus "fatally flawed". ${ }^{44}$ Perkins draws attention to the following passage:

It is the sign of a well brought up child to be inclined to say it is sorry without too much pondering whether it is in the right or not, and it is likewise a sign of a high-minded person and a deep soul if he is inclined to repent, if he does not take God to court but repents and loves God in his repentance. ${ }^{45}$

Perkins argues that in basing repentance upon an inclination, the Judge effectively "uses the same basis for life as the aesthete". 46

In respect of all this, I conclude that, in spite of the flaws of the aesthetic life, Rudd has not succeeded in showing that the ethical as defended by Judge William genuinely is an advance on the aesthetic. Rudd certainly recognises that there are limits to the Judge's position, ${ }^{47}$ but he still seems to suppose that the position the Judge represents is a clear move in the right direction (albeit an incomplete one). What I am arguing is that unless we can give a reason for why the Judge's insight trumps A's, we have no clear grounds for this conclusion. 
Rudd also recognises the possibility that an aesthete may not be convinced by the Judge's case. However, he claims, in such a case the ethicist will judge the aesthete as "a victim of false consciousness, someone who will not acknowledge his own nature because he is frightened by the demands that this might impose upon him. But the ethicist will not suppose that his inability to convert the aesthete shows that his own views are wrong - he finds his way of life justified by the way in which it satisfies the need he feels for narrative structure in his life." ${ }^{48}$ This response will not do. For here we have switched from the question motivating MacIntyre - which concerns an aesthete's judgement about his own life, and whether he could make the "leap" from it without already having "become ethical" - to a quite different question as to what the ethicist thinks of the aesthetic life. That is not the point at issue at all. Moreover, for the reasons given above, it would be just as reasonable to condemn Judge William as the victim of false consciousness as it would to pass this verdict on an aesthete. We might well see the Judge as someone "frightened by the demands" that a genuinely religious life - a life of poverty and adversity that, Kierkegaard claims, no human being would naturally choose to live ${ }^{49}$ - places upon him. From Kierkegaard's ultimate standpoint, the Judge's confidence in the degree of autonomy we can enjoy is a large part of the problem: the degree of control that he implies we can have over our lives is largely illusory. In this sense, the despairing aesthete may even be closer to the religious than is Judge William. ${ }^{50}$ Rudd thus begs the question at issue when he goes on to say: "The fact that one may not be able to argue an aesthete out of his aestheticism does not make aestheticism a rational option. After all, one may also fail to argue a stubborn and consistent flat-Earther ... out of their beliefs; but that doesn't make them rational." ${ }^{, 51}$ This response will not do at all, since Rudd has not provided 
us with any good reason to accept the comparison of what the Judge calls "aesthetic earnestness" with belief in a flat Earth. ${ }^{52}$

Rudd also utilises the most common argument against the aesthetic, which trades on A's mostly tacit, but sometimes explicit, awareness of his own despair. There are two problems with this. First, as noted, it illegitimately dismisses all varieties of the aesthetic life on the basis of dismissing A. The Judge describes A's life as "despair itself", and this, in his view, is the highest vantage point the aesthetic life can attain, in that it has "seen through the vanity of everything, but ... not gone further". ${ }^{53}$ (This latter point is, for the Judge, its crucial flaw.) Yet - and this is the second point Kierkegaard's view of despair (discussed at length in The Sickness Unto Death, authored by the Christian pseudonym Anti-Climacus) ultimately rests on a certain kind of Christian anthropology to the effect that all varieties of human life short of Christian faith count as instances of despair. Once we have noted this, it becomes relatively uninteresting to note that A specifically is in despair - or, indeed, that aesthetes more generally are. Indeed, Rudd himself shows how Judge William's position is likely to end up in despair too. ${ }^{54}$

Let us recap the argument so far. Can the limitations of the aesthetic life be captured by the idea that its "narrative" is incoherent or unintelligible? No. While agreeing with Rudd on the by now standard view that MacIntyre's "criterionless choice" objection is misconceived, I have argued, contra Rudd, that Judge William's argument for the ethical contains far more in the way of substantive normative content than can be encapsulated in the idea of "narrative unity" or "narrative structure". The meaning of the term "narrative" is far from clear, but that aspect which Rudd places centre- 
stage - the MacIntyrean claim that narratives confer intelligibility - will not enable us to distinguish a Kierkegaardian aesthete from a Kierkegaardian ethicist. This is because the objection that the aesthetic life, in all its varieties, is unintelligible is misplaced. We have not been told exactly why fissured, fragmented narratives are ipso facto incoherent or unintelligible. But nor have we been shown that an aesthetic life necessarily is fissured and fragmented, as the Judge's acknowledgment that there are aesthetic lives possessing a kind of unity and coherence recognises. To judge a life as morally shabby or as failing to realise its telos is not - at least, not without considerable further argument - the same as judging it as incoherent or unintelligible. $^{55}$

However, suppose the following response were to be offered on behalf of Rudd (or, indeed, any MacIntyrean Kierkegaardian): "You claim that the term 'narrative' is vague, and too broad to be of much use. But what I mean by 'narrative' and 'narrative unity' is essentially what MacIntyre means by those terms. Understand that, and you will better understand my position."

In the following section, I shall take up this challenge. I shall argue that if we do look in more detail at MacIntyre on narrative, we shall come across even more problems with the "narrative unity" view than we have noticed hitherto. Those problems, in brief, are as follows. First, by taking literary narratives as the default kind of narrative, MacIntyre offers a misleading guide to understanding human life. Second, our very status as temporal beings, far from supporting the "narrative unity" view, resists the idea that any human life could be "unified" or "whole", leaving it very unclear what MacIntyre means when he talks about the importance of having a sense of one's 
"whole life". Third, there are always multiple, possibly radically inconsistent, narratives that could be told of any significant event. This throws up the important problem of self-deception. What justifies the selection one makes of the material that goes to make up the "narrative" of one's life? How can we be confident that we are not just telling stories of our lives that are, in Quinn's words, "retrospective illusions"? Let us consider each of these issues in turn.

\section{Deeper into MacIntyre on narrative: life, literature, temporality and self- deception}

As previously mentioned, I have no quarrel with MacIntyre's observation that an apparently unintelligible utterance can become intelligible by embedding it in a wider context or "narrative". The real problems with his account of "narrative" arise, as Peter Lamarque has recently pointed out, when MacIntyre starts to take literary narrative as the default kind of narrative. In a discussion of conversations, he claims that "we allocate conversations to genres, just as we do literary narratives". 56 Conversations are "dramatic narratives" in which "the participants are not only the actors, but also the joint authors, working out in agreement or disagreement the mode of their production" ${ }^{57}$ Like literary works, conversations have beginnings, middles and ends; many of them have digressions and subplots. But this is true also of "battles, chess games, courtships, philosophy seminars", and so on. Thus, MacIntyre concludes, conversations in particular and human actions in general are "enacted narratives". 58 
Lamarque is right that MacIntyre's use of literary narrative as the guide to understanding human life is misleading. To see why, consider first MacIntyre's suggestion that in writing the biography of a life, we need first to ask to what genre it belongs. (In order to write the life of Thomas Beckett, he insists, we would need to know that it properly belonged to the genre of tragedy rather than hagiography or saga ${ }^{59}$ ) Two questions arise here. First, exactly what is involved in judging a life as a tragedy? John Christman suggests that the life of a completely dissociated personality could count as an example of such. ${ }^{60}$ Or, if we define tragedy more traditionally, such that it is a narrative in which a person with some tragic flaw "suffers a final fatal misfortune", then "the condition of narrativity will be too demanding to account adequately for the variety of lives that real people tend to live". ${ }^{61}$ Second and more fundamentally, why suppose that it is appropriate to allot human lives to such fictional genres at all? Even if this were an appropriate question for the biographer, it hardly seems so to anyone trying to get clear on her own "life narrative". Judging my life as a tragedy on the basis of critical aspects of it to date may well prevent me from seeing ways in which possibilities open to me right now prevent its continuing along such a trajectory. And it is not clear how this talk of allotting a life to a given genre in order to know how to write it is consistent with MacIntyre's later claim that "it is crucial that at any given point in an enacted dramatic narrative we do not know what will happen next". ${ }^{62}$ Could my life change genre at any moment, then? This seems a strange basis on which to build an account of stable selfhood.

It is worth noting that in distinguishing his position from MacIntyre's, another significant narrative theorist, Paul Ricoeur, criticises MacIntyre on just this point of being misled by using literary narratives as his model. MacIntyre, argues Ricoeur, 
"does not attach any decisive importance ... to the split between literary fictions and the stories he says are enacted" ${ }^{63}$ For instance, although for MacIntyre a life cannot be successful or complete unless it can "be grasped as a singular totality", ${ }^{64}$ Ricoeur points out that this is problematic: whereas novels have beginnings and ends, "there is nothing in real life that serves as a narrative beginning; memory is lost in the hazes of early childhood; my birth and, with greater reason, the act through which I was conceived belong more to the history of others - in this case, to my parents - than to me. As for my death, it will finally be recounted only in the stories of those who survive me. I am always moving toward my death, and this prevents me from ever grasping it as a narrative end., ${ }^{, 65}$

This connects with our second point. In similar vein, Stephen Mulhall has recently argued that our status as temporal beings resists any idea of human existence as unified or whole, because of our being-ahead-of-ourselves. We relate ourselves to what is not yet, coming to an end only at death. MacIntyre treats death rather brusquely as the end of the narrative of a given life. Against a critic who objects that "life has no beginnings, middles or ends" - the point being the essentially Sartrean one that we impose such significance on life retrospectively - MacIntyre responds that "one is tempted to reply, 'But have you never heard of death?"' ${ }^{66}$ But Mulhall argues, in parallel with Ricoeur, that it is precisely death that poses a problem for MacIntyre's narrative conception of the self. If my death is necessarily not an event in my life, I cannot grasp it as an episode in the story of my life. My death can be experienced only from a perspective outside my life: it can be an event in the lives of the descendants and friends I leave behind and the drunken driver who ran me over, but not in mine. So MacIntyre's "concept of a self whose unity resides in the unity of 
a narrative which links birth to life to death as narrative beginning to middle to end"67 needs to be handled with great care, since the one person whose unified "life narrative" I can't in principle have access to is my own.

Moreover, Mulhall points out that “to take oneself as one's own intentional object is to take up another state of oneself" ${ }^{68}$ When I am watching a particularly good soccer match, I can get thoroughly absorbed in the action, and entirely unaware of being so absorbed. But I can suddenly be made aware of this absorption by the person over whose shoes I am spilling coffee because I started pouring before my attention was distracted by the beginning of Thierry Henry's mazy run. When this is pointed out to me, I can make the fact of my absorption a new object of consciousness, but in doing so, I take up another state of myself, relegating my previous state to my past. The point here is that one can be conscious of oneself only as one was, not as one is. Thus as Mulhall puts it, "the phenomenon of self-consciousness ... condemns the self to non-self-identity, to a necessary inability to coincide with itself, to gather itself up as a whole into its own awareness". ${ }^{69}$ More prosaically, let us say this: when I reflect on my life at any given point and try and make sense of it as a unity (whatever that turns out to mean), I must necessarily leave out the future in an important sense. The future is both a crucial part of my life, as Heidegger stresses, and yet always a threat to whatever "unity" I may have achieved. Of course, there is one circumstance in which this is not true: the point at which I have no future. But unfortunately, this is the point at which I am dead, and so the issue of the "narrative unity" of my life cannot by that point be an issue for me at all. In Mulhall's words, "the self necessarily transcends any narrative it might be in a position to tell about itself, since any such narrative will always fail to include the moment of its own narrating, and the inclusion of that 
moment will necessarily fail to include the moment in or through which it is included, and so endlessly on". ${ }^{70}$ Thus, he concludes, "any adequate conception of the self as a narrative unity must acknowledge that the self simultaneously and necessarily resists subsumption in a unified narrative."71

It is worth noting that Kierkegaard himself reaches essentially the same conclusion. In a famous journal entry, he observes:

Philosophy is perfectly right in saying that life must be understood backwards. But then one forgets the other clause - that it must be lived forwards. The more one thinks through this clause, the more one concludes that life in temporality never becomes properly understandable, simply because never at any time does one get perfect repose to take a stance: backwards. ${ }^{72}$

Despite this, Macintyre talks about the need to understand the narrative of one's "whole life". Yet, as well as the points above, what justifies supposing that I have any right to think that my life as a whole will, at any given point, consist of a well-ordered story with a perspicuously viewable "shape"? As Christman points out, "most people's lives consist of entirely separable projects and goals which, though each has an internal organizing aim, fail to interconnect in a grand scheme". ${ }^{73}$ Christman's point here, I take it, is not that I do not need to decide how to balance the demands of work and family commitments, for example, in my life. It is rather that I should not necessarily feel any obligation to bring each and every aspect of my life under one grand narrative. For example, my life is ethically none the worse for the fact that I have given little if any thought to the question of how to "unify" my life qua gardener with my life qua soccer fan. (Except in the utterly trivial sense that I can't tend the 
roses while at the game.) Yet any account of my "whole life" - unless that phrase turns out to mean vastly less than it promises - will have to take such factors into account. In telling the story of any given life, Christman adds, we can certainly posit "final purposes to which all our training and experiences inexorably lead. But these are (mostly) the stuff of fanciful biographers rather than plausible structural accounts of everyday lives" ${ }^{74}$ Fanciful biographers or, we might add, looking ahead to the issue of self-deception, fanciful autobiographers.

Exactly what Macintyre means by a "whole life", then, is unclear. He discusses criteria for "success or failure in a human life as a whole" in terms of a "narrative quest", and asserts that "[t]he unity of a human life is the unity of a narrative quest". 75 The answer to his own question - "A quest for what?" - is that no quest could begin without a telos, and so that in construing a life as a quest, some conception of the good for man is needed. On the other hand, the medieval conception of the quest is not a case of searching "for something already adequately characterized, as miners search for gold". ${ }^{76}$ Only through undertaking the quest is its goal finally to be understood, and so a quest "is always an education both as to the character of that which is sought and in self-knowledge". 77

But this still leaves obscure at what point in my life I could say that its "quest" becomes clear to me. Perhaps never, since Macintyre's conclusion about the good life for man is that it is "the life spent in seeking for the good life for man". ${ }^{78}$ And this, as Rudd himself notes, sounds "disappointingly empty" 79 
The impact of this discussion of one's "whole life" on Rudd is as follows. Rudd claims that we ask ourselves "Do I, on reflection, find my life to be meaningful, find that it embodies a coherent narrative?" 80 and suggests that "when we can find no coherent narrative structure in our own lives, we feel lost - despairing, even". ${ }^{81}$ But only in extreme cases of crisis in life, surely, are we likely to ask such questions of our lives as a whole. And such occasions are rare: many seem to go through life without ever facing such a crisis. Far more common is to ask a related question in respect of some aspect of one's life, such as when faced with a decision as to whether or not to accept a new job, or to continue with (or bail out from) a romantic relationship. And while it is true that such aspects of life cannot be separated off from others (MacIntyre's point about the atomistic), this is still not a question about the meaning of my life as such (still less "life" as such). It is far from obvious that questions such as "Should I accept that job in Arizona?" or "Should I get back together with Sarah?" need necessarily lead me to a question as large as "Is my life meaningful?" There is an important difference between asking whether particular aspects of a life hang together, and of whether a "whole life" does, and the former experience is far more common than the latter. ${ }^{82}$

Moreover, the fact that I hesitate to construct an overall narrative of my "whole life" in no way implies that I lack substantial projects and ethical commitments, or that I cannot tell a coherent story about those projects and commitments (including how they hang together). Yet as Lamarque points out, "only in the rarest of cases - full biographies or autobiographies - do individual narratives offer anything like a comprehensive coverage of whole lives. Few people even attempt to tell the complete story of their lives ... Yet if the unity of a life somehow depends on the unity of a 
narrative then most lives will turn out to have no such unity because there is no such narrative". 83

In summary, then, because I am a temporal being who relates myself to the future, no narrative I could ever tell about my "whole life" could ever fully make it a "unity" in any full and robust sense of the term. Thus it is unclear what MacIntyre's talk of one's "whole life" could mean. Talk of a "narrative quest" is similarly obscure, since it is not clear at what point in my life I could ever say that its quest had definitively become clear to me. But having an account of the narrative of one's "whole life" is simply not necessary in order to make sense of the projects and commitments in our lives.

This brings us to the third problem with MacIntyre's talk of "narrative unity": indeterminacy and self-deception. Lamarque puts the problem thus:

the very theory of narrative undercuts the aspiration of life-wide unity, given that narratives are characterised by their perspectival nature. For important sequences of events most people have more than one narrative to tell. All of us return to the major events in our lives and recount them over and over in different narratives from different points of view. The whole idea of unity and coherence crumbles away. The more important the event the more perspectives it invites, thus the more narratives we relate, often in conflict with each other. ... Fragments of narrative, sometimes in conflict with each other, are no basis for an account of personal identity or the unity of a life. The impression given by the term "narrative" is of a complete, rounded story with a beginning, middle and end that helps make sense of complex 
events. The model is historical narrative or the complex narratives of fiction.

But personal narratives virtually never attain completeness, closure or

unity... a misleading paradigm is invoked. ${ }^{84}$

This throws up a very important challenge that any narrative conception of the self must face: the problem of self-deception. What if the stories we tell about our lives are, in Quinn's words, "retrospective illusions" ${ }^{85}$ ? As Quinn points out, there is plenty of room for "self-interested misunderstanding, rationalization, and mythologization" in respect of our own lives. This could either take the form of replacing an "unflattering unified narrative" with "one that feeds our self-esteem", or (for someone sympathetic to Rudd's position) to our constructing such a narrative precisely to assuage the fear that "our lives really lack narrative unity all the way down and are, to that extent, without meaning". ${ }^{86}$ In selecting the material for our life narratives, what justifies the selection? ${ }^{87}$

Interestingly, Kierkegaard's conception of the aesthetic life nicely illustrates this very point. Jeffrey Turner has argued that Kierkegaard is aware of the seductive danger of the aesthetic in a way that "narrative theorists or ... commentators on MacIntyre" 88 have overlooked. Turner argues that the desire to "tell a good tale" about our lives renders us prone to various kinds of self-deception as we try to convince ourselves that our lives are more beautiful or interesting than they really are ${ }^{89} \mathrm{We}$ are, in MacIntyre's famous phrase, "story telling animals", and none of us wants to tell stories about ourselves that are dull or ugly. However, this leads Turner to make the strange claim that "a minimal condition of the moral truth of the stories we tell about ourselves might well be that they can't be boring". ${ }^{90}$ This strikes me as a serious 
wrong turning, for what has the truth of a story has got to do with its interest-value? Turner's claim that we "cannot help but desire to tell and hear interesting and beautiful tales"91 should surely be seen as a potentially self-deception sponsoring problem, rather than something to which we need to accede.

For instance, consider someone who tells the following story:

"The reason I have so often been unfaithful to my wife is because fidelity is just fundamentally at odds with my character. I am a creative artist, and live much of my life in a state of intense creative tension. The mundane rules of conventional morality can hardly be thought to apply to someone like me, whose Art would suffer if contained by such bourgeois notions of propriety. Yes, my wife gets hurt, and yes, that's regrettable. But she has learned to deal with it; indeed, having to face these pitfalls has strengthened her character. We have come to see her turning a blind eye as a way in which she contributes to my Art."

To this, someone might reply:

"No, the reason you have often been unfaithful to your wife is that you are an immature, libidinous old rake who, faced with an attractive and available younger woman, is constitutionally incapable of keeping your trousers on." Now, note that the second, more straightforward story is probably less "interesting" than the former; it is certainly less "beautiful". But neither of these facts in any way detracts from the likelihood, in a given case, of the second story being closer to the truth. 
The above reveals an important danger for which anyone holding a narrative view of selfhood needs to be on the look-out: the danger of conflating the quality of a life with the quality of the narrative of that life. Yet fiction provides us with plenty of examples of wasted, worthless or downright evil lives that make for valuable, rich and fascinating narratives. ${ }^{92}$ So the question that arises for MacIntyrean Kierkegaardians is as follows. Why should we consider that my ability to give a "structure" or "unity" to my life by telling myself (or you) a story about how its component features hang together mean that the unity thus imparted is in any way genuine $?^{93}$

In asking myself whether my life possesses narrative unity, I shall be waging a perennial battle against self-deception. What compounds this problem is the fact that establishing truth in respect of narrative is a tricky business. I can offer you an account of my life that contains not a single falsehood. And yet the overall narrative can still be false and dishonest, insofar as it offers a bowdlerised version of events: for instance, in R. G. Collingwood's words, its “omissions" may be "falsifications". 94

In summary, then, what is the impact of these criticisms of MacIntyre on Rudd and any other Macintyrean Kierkegaardian who would argue along similar lines? First, they do not, of course, in and of themselves render talk of "narrative" null and void: Ricoeur's criticisms of MacIntyre do not prevent him from continuing to talk of his own position in terms of narrative. But the first question for Rudd is this. In saying that the Judge's argument in Either-Or is essentially the same as chapter 15 of After Virtue, and endorsing the Judge as having made an important advance on the aesthetic life, just how much of MacIntyre's argument in that chapter is he endorsing? For the latter argument contains not just the reasonable point that something initially unintelligible might be made more intelligible by embedding it within a wider context 
or narrative, but also - for instance - the conflation of lived human lives with literary narratives and the treatment of those lives as if they belonged to genres, claims nowhere to be found in Either-Or part II. Second, it is unclear exactly what MacIntyrean Kierkegaardians mean to endorse in respect of the "unity" part of the "narrative unity" formula. For a temporal being to attain a strong, "complete" unity in her life is impossible, for Ricoeur's and Mulhall's reasons. There is, of course, a far more minimal sense of unity. However fragmented my life, it is a unity in the minimal sense that is in some sense "mine". Even the most radical schizophrenic, one of whose multiple personalities seizes the reins every ten minutes, can probably still give a name when his psychiatrist's secretary tries to book him in for his next session. In other words, the narrative of any individual life is necessarily a unity in some sense. But insofar as even a schizophrenic, let alone a Kierkegaardian aesthete, possesses "unity" in this sense, such a sense of unity is clearly too minimal to do any useful work for the MacIntyrean Kierkegaardians" case. So the question is this. Exactly where on this continuum do they see their sense of "unity" as sitting? Until I know what kind of "unity" is intended, it is impossible to judge to what extent my (or any other) life has at any given point attained it. And this lack of clarity is fuel to the fire of self-deception. Since MacIntyre's argument conflates literature and life in a misleading way; seems to trade on a conception of the unity of a life that is at best obscure, at worst incoherent; and fails to address the self-deception problem, how much of this argument is Rudd signing up to? ${ }^{95}$

Let us pause to note two further things before moving on. First, we have noted above that self-deception is a real problem for the "narrative unity" position. Yet a key part of Rudd's charge against A is, in effect, that he is self-deceived. (Recall the 
comparison of the aesthete with "a stubborn and consistent flat-Earther".) Once again, then, it is not clear how an appeal to "narrative unity" allows us to advance any further than the aesthete. A corollary of this is that we should be sceptical of Judge William's allegation that A is "always afraid of continuity, chiefly because it deprives you of the chance to delude yourself". ${ }^{96}$ In fact, there is no reason to suppose, just because my life has far more continuity than A's, that I am free from the dangers of self-delusion. Indeed, if Quinn is right, seeing more continuity in my life than is really there might be precisely one form that this self-delusion takes. Once again Kierkegaard himself seems well aware of this problem. In For Self-Examination, recommending "earnestness", he glosses this as a "kind of honest distrust of oneself". ${ }^{97}$

Second, consider briefly an objection that might be raised at this point. Readers of Kierkegaard might be wondering why I have not appealed to that text in which he most explicitly discusses the notion of personal "unity", namely the "upbuilding discourse" commonly referred to as Purity of Heart. ${ }^{98}$ This is because the kind of unity Kierkegaard valorises in that text will not help the MacIntyrean Kierkegaardian case. Such unity is not "narrative unity", insofar as narrative unity focuses upon our nature as temporal beings. But according to Purity of Heart, which persistently downgrades the temporal in relation to the eternal, ${ }^{99}$ the reason that "In truth to will one thing can ... mean only to will the good" 100 is that only "the good", a term that Purity of Heart tends to equate with "the eternal", is an "essential" unity. "To will one thing", Kierkegaard insists, "cannot mean to will that which by nature is not one thing". ${ }^{101}$ As Jeremy Walker glosses this, "all temporal existence, and therefore all 
actual objects of the will, must be mere contingent unities - if they are unities at all". ${ }^{102}$ Thus the essential unity valorised by Purity of Heart is not narrative unity.

\section{Unity, wholeheartedness and "missing the adventure"}

I turn now to a different line of objection to the case for "narrative unity". In the previous section, we considered problems with the notion of "narrative unity" itself. In this third and final section, I shall raise a wider question. Even if the worries raised so far could be addressed, and a clear and coherent account of narrative unity given, just how desirable for a human life is unity and harmony? Turning my attention from Rudd to Davenport and his attempt to build on the work of Harry Frankfurt in a Kierkegaardian context, I shall argue for two claims. First, that Frankfurt and Davenport tend to exaggerate the degree to which we can anticipate and plan our futures. Second, that the desire for unity and wholeness brings with it an important danger: a certain kind of moral blindness.

In response to some of his fellow contributors to Kierkegaard After MacIntyre, Philip Quinn has suggested that "narrative unity" (to the extent that we can make sense of the term) may not really be as desirable as its champions suppose. Quinn suggests that “relinquishing a certain amount of rational control over one's life in order to allow space in it for some disunity, either psychic or narrative, [is] a price worth paying to purchase opportunities to pursue plural but potentially conflicting goods if they are great enough."103

The danger to which Quinn points here is of being insufficiently aware of "the pressure to simplify by exclusion that the yearning for unity and wholeness puts on the ethical life". ${ }^{104}$ There are at least two elements to this. The first is Quinn's concern 
about "retrospective illusions": that we often deceive others and ourselves by leaving out the details of our past life that don't fit the version of the story that we want to tell. The second concerns a prospective danger: that faced with a potentially life-changing decision, we might opt for the line of minimising risk and thus, in Cora Diamond's phrase, "miss the adventure" in life. ${ }^{105}$ Quinn suggests we need "to welcome plural values into our lives, risking the possibility of tragic conflict among them, and to manage the inevitable tensions as creatively and skillfully as we can". ${ }^{106}$ I shall argue that this is right, and that supporters of narrative unity put too strong an emphasis on psychic harmony. Interestingly, in their editors' introduction, Davenport and Rudd remark: "There is surely something to the alternative picture Quinn presents, and we are indebted to him for prompting us to reconsider how we interpret the ideal form of the self". 107

In an interesting pair of articles, Davenport has identified Kierkegaardian choice (of the kind that Judge William urges A to adopt) with Harry Frankfurt's notion of volitional identification. ${ }^{108}$ Frankfurt discusses a kind of "psychic instability or conflict" he labels "ambivalence" of the will. ${ }^{109}$ The person thus afflicted is prevented from "settling upon ... any coherent affective or motivational identity". ${ }^{110}$ In such a state, a person has unavoidably conflicting volitional tendencies that are internal to that person's will. Unlike (to use Frankfurt's example ${ }^{111}$ ) the unwilling addict sincerely struggling against drug addiction, who temporarily gives in to his craving for one more heroin fix and whose will is thus defeated, the ambivalent person's will is divided. Whereas the unwilling addict has a "higher order" desire to get off the stuff, the ambivalent person "does not know what he really wants". ${ }^{112}$ 
Frankfurt opposes ambivalence to wholeheartedness: "A person is volitionally robust when he is wholehearted in his higher-order attitudes and inclinations, in his preferences and decisions". ${ }^{113}$ In qualified but broad agreement, Davenport suggests: wholeheartedness ... typically involves some readjustment of our different priorities, and sometimes the rejection of projects and ends incompatible with other commitments we find more important, until we have reinterpreted or refashioned our ground projects so that they are mutually reinforcing in spirit (rather than pulling in opposite directions), and so that they can all be pursued together (each in its proper respect) in one harmonious life. ${ }^{114}$

He calls this the goal of "existential coherence", and claims that "[a]ll mature human agents wholeheartedly will this sort of practical coherence in their life". 115

One problem with this is that Frankfurt's and Davenport's picture operates at too great a level of generality. For Frankfurt, I am ambivalent if I am uncertain whether to be for or against "a certain psychic position". ${ }^{116}$ But the level of abstract generality employed by Frankfurt's rather skeletal account makes it difficult to know exactly what he means by this. He accuses the ambivalent person of "a sort of incoherent greed - trying to have things both ways". ${ }^{117}$ But how does this cash itself out in the case of a few examples? Consider three.

1. A woman feels uncertain as to whether she should go through with her wedding. The church and reception hall have been booked, and the invitations sent out. Yet she is having serious doubts about whether she and her fiancé are really right for each other. Does she love him? Yes, but perhaps not enough. Would she miss him if they split up? Yes, she thinks, but perhaps she's really more worried about the effects 
rejection might have on him. She's started to suspect that he loves her more than she loves him, and she thinks that this is not a healthy basis for a marriage. Perhaps her reluctance to do the brave thing and call it off is motivated more by cowardice than genuine love. In Frankfurt's terms, she doesn't know what she wants. Should she stay or should she go?

2. A young philosophy professor's career has started encouragingly well. He's on track for tenure, is getting good teaching evaluations, and his first book has just come out to enthusiastic reviews. He genuinely enjoys most aspects of his job - and yet something is missing. He's always hankered for more literary freedom than academic writing affords him, and since his teens has always really wanted to be a novelist. He uses whatever extremely limited spare time he can find, when his wife is in bed and the baby is finally asleep, to work away at that manuscript in the bottom drawer. $\mathrm{He}$ could get the manuscript finished if it weren't for his full-time job at the university. He could, of course, jump off the career ladder and devote himself full-time to the novel - but then how would he pay the bills? That would surely be grossly irresponsible given his family duties. Perhaps, then, he should give up on his dream altogether. But what kind of person would that make him? He'd be living with his regret, and perhaps thereby coming to resent those around him. Perhaps then he should continue with the current arrangement. But suppose trying to be both a philosopher and a novelist leads him to fail at both? Moreover, it might not be until the very end of his life that this fact becomes clear: that what was possible for Sartre and Iris Murdoch has not been possible for him. What should he do? 
3. A young lawyer's career is also going well, and he too is engaged. Yet although his fiancée tolerates the amount of time he spends at the office, she doesn't really understand how important his career is to him. Her commitment to conventional family life is far greater than his, and he knows that once they are married, she will want kids within a year or two. He's worried that this scenario will prevent his climbing the corporate ladder. Maybe he won't make partner within five years, which was always his goal. Should he call off the wedding, dump his fiancée and focus exclusively on his career?

What would Frankfurt say about these cases? They range from genuine and I take it understandable cases of ambivalence (the first two) to a case (the third) in which one concern - career - borders on the monomaniacal. Yet against the background of such real-life cases, Frankfurt's advice to "know what we want" rings false to the complexity of the lived moral life. ${ }^{118}$ How can we necessarily judge in advance what we should want? As Stanley Cavell points out, in both art and life, "you do not know in advance what may arise as a significant detail". ${ }^{119}$ Also, is it clear that the philosopher who also wants to be a novelist is guilty of an "incoherent greed"? It seems unfair to compare him unfavourably with the career-obsessed lawyer, whom I take it most of us would advise to think about things other than just his career. Yet the philosopher is the more ambivalent of the two.

Quinn suggests that the "Apollonian" stress on the internal harmony of the self emphasized by Frankfurt and Davenport needs to be complemented by a more "Dionysian" element that recognizes that "human values are irreducibly plural, inexhaustible, sometimes incommensurable, and often conflicting". ${ }^{120}$ The ability to 
appreciate a wide diversity of values is itself a significant component in the overall meaningfulness of a human life. Now, Davenport makes clear that by unity he does not have in mind a single-minded devotion to one theme in relation to which the rest of life is subservient (such as in the case of the career-obsessed lawyer). Rather, he says, it can be "the unity of a narrative with a wide range of diverse themes and subplots involving values that are incomparable or not ranked on any single objective scale". ${ }^{121}$ But this will not help unless it is made clear wherein the unity of a narrative is supposed to consist, and this is precisely the clarification that MacIntyrean Kierkegaardians owe us.

I suggest that the focus on unity and wholeheartedness, despite its prima facie appeal, is potentially dangerous insofar as it can sponsor a kind of existential myopia. Another way of putting this point is that there is a potential tension between wholeness and well-roundedness. ${ }^{122}$ If we maintain wholeness by limiting the diversity of our commitments, we might miss, in Jeffrey Blustein's words, the invigorating effect of variety, as well as the chance to enrich our lives by being open to feelings, attachments, and values that incline us in different directions ... by giving greatest weight to wholeness in the conduct of our lives we neglect an important dimension along which lives may be evaluated... A well-rounded life of coherent commitment may be a better life for a person to live than a life that sacrifices well-roundedness for wholeness despite the greater difficulty of achieving and maintaining integrity in these circumstances. ${ }^{123}$ 
I think Blustein is right. We can see why by considering a distinction sometimes made, along similar lines to Frankfurt and Davenport, between unconditional (or “identity-conferring”) and defeasible commitments. ${ }^{124}$ John Kekes, for example, has argued that the feature of integrity he labels "wholeness" or "constancy"125 involves adhering to "the pattern of hierarchically organised commitments that compose one's life". ${ }^{126}$ Blustein glosses this as follows: "A commitment's ranking in this hierarchy is a function of the status the agent accords it so far as core identity or life-plan is concerned." ${ }^{127}$ Crucial to this way of thinking is the distinction between commitments that are "unconditional" and those that are merely defeasible. On this view, if a defeasible and an unconditional commitment come into conflict, the latter should take precedence if integrity is not to be lost. As Kekes puts it, "we must learn to distinguish between the centre of our character, where our deepest commitments lie, and the outer layers, which we can afford to compromise, if need be". ${ }^{128}$ A central task of the virtue Kekes labels "self-direction" is "to draw and maintain this distinction". 129 "To have a coherent character", he claims, "is to have made unconditional commitments". ${ }^{130}$ Self-direction "is conditional on living according to one's unconditional commitments and according to as many of one's defeasible and loose commitments as circumstances allow." ${ }^{, 131}$

This line of reasoning is indeed likely to have a prima facie appeal to anyone who cares about integrity. But - and this is my point - there is a problem. What such an approach seems to presuppose is that the ethically exemplary person operates with two reasonably explicit lists of commitments - one unconditional and one defeasible and that it is not possible for these commitments to switch lists. Such a picture takes insufficiently seriously the possibility of a kind of moral "aspect-dawning”, akin to 
what Jamie Ferreira calls a "transforming vision", in which, as it were, one's ethical applecart is upturned. ${ }^{132}$ What prevents the possibility of a shift in one's ethical (or religious) vision such that what had previously struck one as merely defeasible comes to seem unconditional, or vice versa? Religious conversion and loss of faith are only the most obvious instances of such a shift. Colin Lyas asks: “couldn't one think that one had been brought to see oneself or the world rightly, and, indeed, live a whole life in the spirit of that revelation and, at the last, come to realize that this was not right?" ${ }^{133}$ Think of Tolstoy's Ivan Ilyich. ${ }^{134}$ Yet this need hardly be a death-bed revelation. As Lyas adds, “our moral views, and more generally our views of life, are constantly brought to the bar of experience and can alter in consequence. We can never be sure when this is going to happen."135

If this is right, then what becomes of Frankfurt's recommendation? Frankfurt claims that in trying to decide which of the many things to which we are attracted are actually going to matter to us, "we must anticipate the extent to which each can be coherently elaborated in our lives". ${ }^{136}$ But how useful is this as a piece of practical advice? To what extent is such anticipation possible? Frankfurt's advice will not enable our hesitant bride to decide whether to go through with the wedding. Her problem is precisely that she cannot "anticipate" what to do for the best. (Or, to put it in the language Kierkegaard uses in Purity of Heart, the problem is precisely with anticipating what would constitute "willing the good in truth" in this situation.) A similar point applies in the philosopher-novelist and career-obsessed lawyer cases though here there is the additional danger that trying to anticipate whether a course of action can be "coherently elaborated in our lives" might lead to unnecessarily limiting decisions. (For example, the fact that our lawyer is unable to see how family life is 
compatible with a successful career might simply amount to a lack of imagination on his part.)

With such concerns in mind, it is useful to contrast the Frankfurtian approach recommended by Davenport with that of Martha Nussbaum. In her discussion of Henry James's The Golden Bowl, Nussbaum focuses upon the process of moral maturity as it develops in the character of Maggie Verver. A crucial part of Maggie's development, for Nussbaum, is her replacement of "little girls' questions" with a more "adult" mode of moral deliberation as she comes to question the nature of her attachments to her husband and her father. Crucial to this is precisely an increased scepticism about what we can "anticipate":

When are we to pursue this ideal and when to let it go? How much is deep love worth, and under what circumstances is it worth a blinding? What boundaries are we to draw? What priorities can we fix? These, I take it, are the little girls' questions ... She wants to be told ahead of time exactly what's right and when. She wants to know exactly how much she loves this person, and exactly what choices this entails. To counter her insistent demand, James repeatedly, in the second half of the novel, holds up to us a different picture: that of an actress who finds, suddenly, that her script is not written in advance and that she must "quite heroically" improvise her role ... The final understanding to which his criticism of little girls transports us is that this is what adult deliberation is and should be. And there's no safety in that, no safety at all. ${ }^{137}$ 
Note the claim: mature ethical deliberation involves openness to risk and readiness to venture into uncharted waters. To refuse this is to "miss the adventure" that life throws at us. In an illuminating discussion of Nussbaum, Cora Diamond quotes the mountaineer George Mallory: "To refuse the adventure is to run the risk of drying up like a pea in its shell. Mountaineers, then, take opportunities to climb mountains because they offer adventure necessary to them."138 Both Mallory's sense of adventure and that which James and Nussbaum see as central to the moral life "involve the response of the quickened sense of life to what is appreciated as having its mysteries and depths and uncertainties and dangers; both involve an openness to surprise". ${ }^{139}$

On Nussbaum's picture, “a fixed antecedent ordering or ranking among values is to be taken as a sign of immaturity rather than excellence". ${ }^{140}$ Instead of valorising unity, wholeheartedness and anticipation, Nussbaum claims that "it is the job of the adult agent to approach a complex situation responsively, with keen vision and alert feelings, prepared, if need be, to alter his or her prima facie conception of the good in the light of the new experience". ${ }^{141}$ In The Golden Bowl, she claims, we are shown that an excessive focus on harmony "followed out to its strictest conclusion, generates an extraordinary blindness to value and ends by subordinating the particular claim of each commitment and love to the claims of harmony". ${ }^{142}$

In a recent discussion of Frankfurt and his critics, Marya Schechtman puts a version of this point as follows. Drawing on the comparison often made, ever since Plato, between selves and states, Schechtman suggests that Frankfurt's critics have accused his picture of "over-estimating the danger of internal civil war". ${ }^{143}$ Even if Frankfurt's 
insight that freedom has little value if we do not know what we want has merit, it is just as important to realise that self-constraint can become unhealthily repressive. In line with what Quinn and I are suggesting, Schechtman suggests that "the work of shaping a life is less of a task of micro-management" $" 144$ than the Frankfurt picture sponsored by Davenport encourages us to think. "It is less about directly settling conflicts than about establishing safe boundaries within which these conflicts can be allowed to play themselves out."145

Overall, then, I am making two claims in this section. First, that Frankfurt and Davenport tend to exaggerate the degree to which we can anticipate outcomes and plan our lives accordingly. Second, that such a focus on "unity" overlooks an important aspect of moral vision. If we are not careful, our determination to follow our "life-plans", to pursue our "goals", threatens to lead to a kind of moral blindness, a lack of moral imagination. This is at least as serious a danger as the lack of direction of which Judge William accuses A. As Diamond puts it, "Seeing the possibilities in things is a matter of a kind of transforming perception of them". ${ }^{146}$ The problem is this: what reason do we have to be confident that those "wholeheartedly willing to be wholehearted" are those best placed for this kind of transforming perception or vision? Might not more openness, and less wholeheartedness, often serve us better?

I do not want to deny that self-choice, wholeheartedness and self-direction are important components of an ethical life. But I do want to support Quinn's claim that there are serious dangers with putting too much emphasis on such aspects. For perhaps the clearest way in which to see how too "pre-planned" a picture risks oversimplifying what a human life is like, consider love: more precisely, that dimension of 
love which requires a willingness to be transformed by the other, such that it becomes difficult to say where your plans and "goals" end and his or hers begin. ${ }^{147}$ In some sense, this involves a willingness to have the "narrative unity" of one's life disrupted or even shattered. ${ }^{148}$ Would supporters of "unity" and "wholeheartedness" deny this? Perhaps their response would be that one should just build this into the next stage of one's life narrative. But again, the threat of emptiness looms large here: if any radical eruption of my life can be fitted into its narrative, it again becomes unclear exactly what the supporters of "narrative unity" are telling us. Once again, we are forced to ask by what criteria we could judge one narrative as "unified" and another as not.

\section{Summary and Conclusion}

In this article, I have argued (in section I) that despite what commentators such as Anthony Rudd have maintained, the MacIntyrean idea of "narrative unity" cannot be used to show the superiority of the ethical over the aesthetic life in Kierkegaard's Either-Or. Judge William's argument for the ethical in fact contains far more in the way of substantive normative content than can be encapsulated in the idea of “narrative unity”. Moreover, the MacIntyre-inspired claim that narratives confer intelligibility will not enable us to distinguish a Kierkegaardian aesthete from a Kierkegaardian ethicist. In section II, I drew attention to serious problems with MacIntyre's own use of the notion of narrative. First, by taking literary narratives as the default kind of narrative, MacIntyre offers a misleading guide to understanding human life. Second, our status as temporal beings resists the idea that any human life could be "unified" or "whole", leaving it very unclear what MacIntyre means when he talks about the importance of having a sense of one's "whole life". Third, the 
perspectival nature of narrative reveals self-deception to be a serious problem. Finally, in section III, I turned to the wider question of whether unity and wholeheartedness are really as desirable in a human life as many suppose. I concluded that supporters of unity and wholeheartedness tend to exaggerate the degree to which we can anticipate and plan our futures, and that a certain kind of moral blindness attends an excessive concern with unity and wholeheartedness. Thus the desire for "unity" in a human life may be a far less urgent need than some have supposed. ${ }^{149}$ 


\section{References}

Blustein, J. (1991) Care and Commitment: Taking the Personal Point of View

(Oxford: Oxford University Press).

Bruner, J. (1990) Acts of Meaning (Cambridge, MA: Harvard University Press).

Cavell, S. (1971) The World Viewed (New York: Viking).

Christman, J. (2004) "Narrative Unity as a Condition of Personhood",

Metaphilosophy 35-5, pp. 695-713.

Collingwood, R. G. (1938) The Principles of Art (Oxford: Clarendon Press).

Currie, G. (1998) “Narrative”, in: E. Craig (gen. ed.) Routledge Encyclopedia of

Philosophy, Vol. 6, pp. 654-657 (London: Routledge).

Davenport, J. J. (2001a) “The Meaning of Kierkegaard's Choice between the

Aesthetic and the Ethical: a Response to MacIntyre", in Davenport and Rudd, pp. 75-

112.

--- (2001b) “Towards an Existential Virtue Ethics: Kierkegaard and MacIntyre”, in

Davenport and Rudd, pp. 265-323.

Davenport, J. J. and Rudd, A. (Eds.) (2001) Kierkegaard After MacIntyre: Essays on

Freedom, Narrative and Virtue (Chicago: Open Court).

Diamond, C. (1991) "Missing the Adventure: Reply to Martha Nussbaum" in her The

Realistic Spirit: Wittgenstein, Philosophy and the Mind, pp. 309-318 (Cambridge,

MA: MIT Press).

Ferreira, M. J. (1991) Transforming Vision: Imagination and Will in Kierkegaardian Faith (Oxford: Clarendon Press). 
Frankfurt, H. (1988) "Freedom of the Will and the Concept of a Person", in his The Importance of What We Care About: Philosophical Essays, pp. 11-25 (Cambridge: Cambridge University Press).

--- (1999) “The Faintest Passion”, in his Necessity, Volition and Love, pp. 95-107

(Cambridge: Cambridge University Press).

Furtak, R. A. (2005) Wisdom in Love: Kierkegaard and the Ancient Quest for Emotional Integrity (Notre Dame: University of Notre Dame Press).

Hannay, A. (1995) “The Judge in the Light of Kierkegaard's Own Either/Or: Some Hermeneutical Crotchets”, in: R. L. Perkins (ed.) International Kierkegaard Commentary: Either/Or, Part II, pp. 183-205 (Macon, GA: Mercer University Press). Irigaray, L. (1992) Elemental Passions, trans. J. Collie and J. Still (New York: Routledge).

James, H. (1934) The Art of the Novel (New York: Charles Scribner's Sons).

Kearney, R. (ed.) (2004) Debates in Continental Philosophy: Conversations with Contemporary Thinkers (New York: Fordham University Press).

Kekes, J. (1983) “Constancy and Purity”, Mind XCII, pp. 499-518.

--- (1995) Moral Wisdom and Good Lives (Ithaca: Cornell University Press).

--- (2002) The Art of Life (Ithaca: Cornell University Press).

Kierkegaard, S. (1967) Journals and Papers, volume I. ed. and trans. H. V. and E. H. Hong (Bloomington: Indiana University Press).

--- [1843] (1987a) Either/Or, volume I, ed. and trans. H. V. and E. H. Hong

(Princeton: Princeton University Press).

--- [1843] (1987b) Either/Or, volume II, ed. and trans. H. V. and E. H. Hong

(Princeton: Princeton University Press). 
--- [1849] (1989) The Sickness Unto Death, trans. A. Hannay (Harmondsworth:

Penguin).

--- [1850/1876] (1990) For Self-examination/Judge for Yourself!, ed. and trans. H. V. and E. H. Hong (Princeton: Princeton University Press).

--- [1846] (1992) Concluding Unscientific Postscript to Philosophical Fragments, ed. and trans. H. V. and E. H. Hong (Princeton: Princeton University Press).

--- [1847] (1993) “On the Occasion of a Confession: Purity of Heart is to Will One Thing”, in Upbuilding Discourses in Various Spirits, ed. and trans. H. V. and E. H. Hong (Princeton: Princeton University Press).

--- [1859] (1998) The Point of View, ed. and trans. H. V. and E. H. Hong (Princeton: Princeton University Press).

Lamarque, P. (2004) "On Not Expecting Too Much from Narrative”, Mind and Language 19-4, pp. 393-408.

Lippitt, J. (2005) “Telling tales: Johannes Climacus and "narrative unity”, in Cappelørn, N. J. (ed) Kierkegaard Studies Yearbook 2005, pp. $71-89$ (Berlin: Walter de Gruyter).

Lodge, D. (1995) Therapy (London: Secker and Warburg).

Lyas, C. (2002) “That's it Exactly!”, in J. H. Whittaker (ed.) The Possibilities of Sense, pp. 238-250 (London: Palgrave).

MacIntyre, A. (1985) After Virtue, second edition (London: Duckworth).

--- (1999) Dependent Rational Animals (Chicago: Open Court).

--- (2001) “Once More on Kierkegaard”, in Davenport and Rudd, pp. 339-355.

McFall, L. (1987) “Integrity”, Ethics 98-1, pp. 5-20.

Mehl, P. J. (2005) Thinking Through Kierkegaard: Existential Identity in a Pluralistic World (Urbana and Chicago: University of Illinois Press). 
Morton, A. (2002) "Beware Stories: Emotions and Virtues” in: Peter Goldie (ed.),

Understanding Emotions: Mind and Morals, pp. 55-63 (Aldershot: Ashgate).

Mulhall, S. (forthcoming) "The Enigma of Individuality: Identity, Narrative and Truth in Biography, Autobiography and Fiction”, in: Richard Eldridge (ed.), Oxford Handbook of Philosophy and Literature (Oxford: Oxford University Press). Page references are to the version delivered at "Life Stories", a conference at King's College, London (2004).

Nussbaum, M. C. (1990a) Love's Knowledge: Essays on Philosophy and Literature (Oxford: Oxford University Press).

--- (1990b) “Flawed Crystals: James’s The Golden Bowl and Literature as Moral Philosophy", in Nussbaum 1990a, pp. 125-147.

Oden T. C. (ed.) (1978) The Parables of Kierkegaard (Princeton: Princeton University Press).

Perkins, R. L. (1995) “Either/Or/Or: Giving the Parson his Due, in: R. L. Perkins (ed.) International Kierkegaard Commentary: Either/Or, Part II, pp. 207-231 (Macon, GA: Mercer University Press).

Quinn, P. L (2001) “Unity and Disunity, Harmony and Discord: a Response to Davenport and Lillegard”, in Davenport and Rudd, pp. 327-337.

Ricoeur, P. (1992) Oneself as Another, trans. K. Blamey (Chicago: University of Chicago Press).

Rudd, A. (1993) Kierkegaard and the Limits of the Ethical (Oxford: Clarendon Press).

--- (2001) “Reason in Ethics: MacIntyre and Kierkegaard”, in Davenport and Rudd, pp. 131-150.

Schechtman, M. (1996) The Constitution of Selves (Ithaca: Cornell University Press). --- (2004) “Self-expression and Self-control”, Ratio 17-4, pp. 409-427. 
Tolstoy, L. (1960) The Death of Ivan Ilyich and Other Stories, trans. R. Edmonds (Harmondsworth: Penguin).

Strawson, G. (2004) “Against Narrativity”, Ratio, 17-4, pp. 428-452.

Turner, J. (2001) “To Tell a Good Tale: Kierkegaardian Reflections on Moral

Narrative and Moral Truth", in Davenport and Rudd, pp. 39-57.

Walker, J. D. B. (1972) To Will One Thing: Reflections on Kierkegaard's Purity of Heart (Montreal: McGill-Queen's University Press).

Walsh, S. (2005) Living Christianly: Kierkegaard's Dialectic of Christian Existence (University Park: Pennsylvania State University Press).

Yandell, K. E. (2001) "Narrative Ethics and Normative Objectivity”, in: K. E. Yandell (ed.), Faith and Narrative, pp. 237-260 (Oxford: Oxford University Press). 
${ }^{1}$ MacIntyre, 1985, p. 205.

${ }^{2}$ Davenport and Rudd, 2001, p. xviii.

${ }^{3}$ For instance, in his attempt to understand Abraham as the paradigmatic exemplar of faith, Johannes de Silentio, the pseudonymous author of Fear and Trembling, tells and retells one specific biblical narrative, the story of the binding of Isaac, in a variety of ways. On Kierkegaard's use of parables, see Oden (1978).

${ }^{4}$ Davenport and Rudd, 2001, p. xix.

${ }^{5}$ Ibid.

${ }^{6}$ Rudd, 2001, p. 131.

${ }^{7}$ Ibid., p. 139.

${ }^{8}$ MacIntyre, 1985, p. 39.

${ }^{9}$ Davenport and Rudd's collection brings together previously published critical accounts of MacIntyre's reading of Either-Or and new essays, many of which advance the line described here. I shall call commentators who view Kierkegaard's and MacIntyre's projects as potential allies "MacIntyrean Kierkegaardians".

${ }^{10}$ Rudd, 2001, p. 138.

${ }^{11}$ One commonly cited specification is that of Jerome Bruner: "a narrative is composed of a unique sequence of events, mental states, happenings involving human beings as characters or actors. These are its constituents ... Their meaning is given by their place in the overall configuration of the sequence as a whole - its plot or fabula" (Bruner, 1990, p. 43). Marya Schechtman quotes this approvingly, but also adds that "[t]o be identity-defining an individual's self-narrative must conform in certain crucial respects to the narrative others tell of his life" (Schechtman, 1996, p. 96). However, it should be noted just how broad the term "narrative" is, and just how 
minimal the conditions are for something to count as a narrative. For instance, Peter Lamarque has recently suggested the following conditions: "at least two events must be depicted in a narrative and there must be some more or less loose, albeit nonlogical, relation between the events" (Lamarque, 2004, p. 394). There is a temporal dimension to narrative, but this can include simultaneity. Thus "I turned the key and the door opened" is, on this minimal definition, a narrative. On such a definition, Lamarque is surely right that "very little of substance can be inferred from the premise that a piece of discourse is a narrative" (ibid.)

${ }^{12}$ As well as Rudd, several other contributors to Kierkegaard After MacIntyreincluding Jeffrey Turner, Norman Lillegard, Edward Mooney and John Davenport also appeal, in various ways, to the idea of narrative. All of their essays are insightful in various ways, but none offers a fully fleshed out account of exactly what they mean by the term "narrative".

${ }^{13}$ Strawson, 2004, p. 439.

${ }^{14}$ Rudd, 2001, pp. 138-139. Note what is and is not being claimed here. Rudd's claim presupposes that the aesthete already has an identity in a certain minimal sense. To lack a "sense" of personal identity is not the same thing as lacking a personal identity. As Keith Yandell puts it, "only something that is already a person can get a sense of identity by identifying with a story. What identifying with the story typically does is to further refine a sense of identity already possessed, but a sense of identity is one thing and identity as a person is another, and however intimately they may be related, they are not identical." (Yandell, 2001 p. 258). For this reason, we can easily be misled by Kierkegaard's talk of "becoming a self”. In order for what he has in mind to make sense, anyone capable of responding to such a call must already a self in some more minimal sense. 
${ }^{15}$ Rudd has confirmed in personal discussion that this is his understanding; Davenport expresses the same view in Davenport, 2001a, pp. 95-96. Compare Kierkegaard's remark that "most people in Christendom ... live in esthetic or, at most estheticethical categories" (Kierkegaard, 1859/1998, p. 43).

${ }^{16}$ Davenport, 2001a, p. 95.

${ }^{17}$ MacIntyre, 1985, p. 209.

18 Ibid., p. 210.

${ }^{19}$ Ibid.

${ }^{20}$ See Kierkegaard, 1843/1987b, pp. 291-293.

${ }^{21}$ Two possible objections need to be considered at this point. It has been suggested that the unintelligibility of one's life to oneself is a more common feature than I allow for, the example being given of kleptomaniacs who are unable to explain why they do what they do. But Rudd is trying to use intelligibility to distinguish aesthetes from ethicists in general, so such an extreme counter-example as this will hardly be enough to support this case. Second, it has been suggested that a person may be mistaken about whether his life is "really" intelligible. Viewed in a certain way, this is indeed a real and present danger, though as I shall later suggest in discussing self-deception, it is a danger that haunts far more than aesthetes (and so once again will not enable Rudd to make the distinction that he wants). But it is crucial here to ask: "Intelligible to whom?" One suggestion that has been made is that one might judge the intelligibility of a given life with reference to an "ideal observer". But such a move will not help at all in respect of the issue at stake between MacIntyre and his Kierkegaardian commentators. That issue is whether an ethicist can give a reason for an aesthete to embrace the ethical life that will be compelling to the aesthete. As Rudd comments elsewhere, "Neat-looking neo-Kantian arguments that appear convincing in 
the abstract, in a philosopher's study, may seem a little hollow if we imagine them being read with A's mocking eyes" (Rudd, 1993, p. 68). Anyone familiar with A's writings will be able to see that appeals to "ideal observers" will meet the same fate. What matters for the argument of Either-Or is not what an "ideal observer" makes of A's (or another aesthete's) life, but how A (or that other aesthete) himself sees it. Judge William's argument, in other words, needs to appeal to the aesthete himself. And this, as Rudd rightly notes, is precisely what the Judge tries to do. I am grateful to the Philosophy Colloquium at St Olaf College for discussion of these points.

${ }^{22}$ Kierkegaard, 1843/1987b, p. 167.

${ }^{23}$ Ibid.

${ }^{24}$ Ibid.

${ }^{25}$ Ibid., pp. 216-217.

${ }^{26}$ Ibid., p. 245, 302.

${ }^{27}$ Ibid., pp. 280-283, 288.

${ }^{28}$ Ibid., p. 28.

${ }^{29}$ Furtak, 2005, p. 77, my emphasis.

${ }^{30}$ Rudd, 2001, p. 131.

${ }^{31}$ Ibid., p. 140.

${ }^{32}$ Ibid., p. 138. The Judge does indeed make this charge against A specifically: that his life lacks continuity and therefore meaning (Kierkegaard, 1843/1987b, p. 195). "You have no life-view", he adds (ibid., p. 202). But whether this is true of A or not, note that it is not intended as a charge against the aesthetic in general. It must be a charge against the position of "despair itself", since other aesthetes have indeed been said to have a life-view: hedonism (ibid., p. 179).

${ }^{33}$ Ibid., p. 180. 
${ }^{34}$ Ibid., p. 183.

${ }^{35}$ Note also that such manifestations of the aesthetic life as this are not, in Peter Mehl's words, lives “without meaning or purpose; my self is not aimless but built around concrete possibilities and talents that I saw (and still see) as live options for my life" (Mehl, 2005, p. 18). What such lives lack, from the Judge's point of view, is that they do not involve "single-mindedly and consistently pursuing the ethical life, where that means that I am always considering whether my identifications and concerns are acceptable" (ibid., p. 19). Mehl is sceptical as to whether this kind of "strong evaluation" is really as necessary or desirable as the Judge supposes.

${ }^{36}$ Furtak, 2005, p. 82, 83.

${ }^{37}$ Ibid., p. 83. On the relationships point, A discusses - with a heavy dose of irony the threat human relationships such as marriage and friendship pose in the essay "Rotation of Crops" (Kierkegaard, 1843/1987a, pp. 281-300).

${ }^{38}$ Furtak, 2005, p. 84. For example, the “confident joy" (Kierkegaard, 1843/1987b, p. 31) the Judge expresses about his own marriage has often been seen as a rather smug complacency rooted in a certain attitude between the sexes. (See Turner (2001) for a particularly interesting treatment of this.) This theme of marital complacency is powerfully brought out by David Lodge in his Kierkegaard-inspired novel Therapy. There is a scene part way through the novel in which the central character, the middleaged comedy writer Tubby Passmore eulogises, after the fashion of Judge William, the comforts of middle-aged, middle-class marriage to a familiar partner: "It's a commonplace that you can always tell which couples in a restaurant are married to each other because they're eating in silence. But does that mean they're unhappy with each other's company? Not at all. ... It's not that they have nothing to say to each other, but that it doesn't have to be said. Being happily married means that you don't 
have to perform marriage, you just live in it, like a fish lives in the sea." (Lodge, 1995, p. 128). On the next page, Tubby's wife tells him that she wants a separation.

("She says she told me earlier this evening, over supper, but I wasn't listening" (ibid., p. 129).)

${ }^{39}$ Rudd, 2001, p. 145.

${ }^{40}$ Ibid., p. 144.

${ }^{41}$ Kierkegaard, 1846/1992, p. 258.

${ }^{42}$ Hannay, 1995, p. 188.

${ }^{43}$ Perkins, 1995, p. 216.

${ }^{44}$ Ibid., p. 217.

${ }^{45}$ Kierkegaard, 1843/1987b, p. 237.

${ }^{46}$ Perkins, 1995, p. 216.

${ }^{47}$ See Rudd, 2001, pp. 145-147; also Rudd, 1993, chapter 4.

${ }^{48}$ Rudd, 2001, p. 145.

${ }^{49}$ For a discussion of such themes in Kierkegaard's religious and specifically

Christian writings of 1847-1851, and their connection with positive correlates such as faith, forgiveness and joy, see Walsh (2005).

${ }^{50}$ Hannay draws on Stages on Life's Way to make a similar point. See Hannay, 1995, p. 190.

${ }^{51}$ Rudd, 2001, p. 145.

52 This part of Rudd's article is confusing, since this line against the aesthete seems curiously at odds with a footnote that immediately precedes it, in which Rudd wonders whether the need for coherence and meaning in our lives really is universal after all. If some people really do lack that need, he concedes, then the ethical "would 
not be a rational choice for them" (Rudd, 2001, p. 149). So what is the overall claim: are aesthetes irrational or not?

${ }^{53}$ Kierkegaard, 1843/1987b, p. 194.

${ }^{54}$ See Rudd, 1993, pp. 141-143.

${ }^{55}$ Rudd himself considers another possible objection, to the effect that "the aesthete is precisely someone who ... does not want to make her life a coherent unity, and who therefore has no reason to respond to the Kierkegaardian argument" (Rudd, 2001, p. 140). He then gives reasons why MacIntyre could not appeal to this argument, given his commitments. But this leaves open the possibility that someone without MacIntyre's commitments could make it. What Rudd's answer to that person would be remains unclear.

${ }^{56}$ MacIntyre, 1985, p. 211; cf. Lamarque, 2004, p. 402.

${ }^{57}$ MacIntyre, 1985, p. 211.

58 Ibid.

${ }^{59}$ MacIntyre, 1985, pp. 212-213.

${ }^{60}$ Christman, 2004, p. 701.

${ }^{61}$ Ibid.

${ }^{62}$ MacIntyre, 1985, p. 215.

${ }^{63}$ Ricoeur, 1992, pp. 158-159.

${ }^{64}$ MacIntyre claims that the unity of an individual life consists of "the unity of a narrative embodied in a single life". To ask what the good is for me is to ask "how best I might live out that unity and bring it to completion", and to ask what the good is for man is to ask "what all answers to the former question must have in common". What provides the moral life with its unity is "the systematic asking of these two 
questions and the attempt to answer them in deed as well as word" (MacIntyre, 1985, pp. 218-219).

${ }^{65}$ Ricoeur, 1992, p. 160.

${ }^{66}$ MacIntyre, 1985, p. 212.

${ }^{67}$ Ibid., p. 205.

${ }^{68}$ Mulhall, forthcoming, p. 23.

${ }^{69}$ Ibid.

${ }^{70}$ Ibid., p. 24.

${ }^{71}$ Ibid., p. 27.

${ }^{72}$ Kierkegaard, 1843/1967, p. 450.

${ }^{73}$ Christman, 2004, p. 704.

${ }^{74}$ Ibid.

${ }^{75}$ Macintyre, 1985, p. 219.

${ }^{76}$ Ibid.

${ }^{77}$ Ibid.

${ }^{78}$ Ibid.

${ }^{79}$ Rudd, 2001, p. 146.

${ }^{80}$ Ibid., p. 143.

${ }^{81}$ Ibid., p. 140.

${ }^{82}$ Some of the other contributors to Kierkegaard After MacIntyre, such as John

Davenport, also adopt MacIntyre's talk of a "whole life" somewhat uncritically.

Davenport claims that the "primordial choice" to enter the ethical life can be helpfully thought of as "the generalized decision to identify with a life plan or stable pattern of first-order motivations that will give an intersubjectively intelligible meaning to one's whole life" (Davenport, 2001a, p. 92). 
${ }^{83}$ Lamarque, 2004, p. 404.

${ }^{84}$ Ibid., p. 405. MacIntyre, remember, talks explicitly in terms of lives as narratives that have beginnings, middles and ends (MacIntyre, 1985, p. 205).

${ }^{85}$ Quinn, 2001, p. 329. Quinn's point is similar to Sartre's objection, though as far as I can tell, Quinn is not committed to a view as strong as Sartre's, to the effect that narrative always falsifies. See MacIntyre, 1985, p. 214.

${ }^{86}$ Quinn, 2001, p. 329.

${ }^{87}$ This is a real problem for MacIntyre's account. MacIntyre claims that "the story of my life is always embedded in the story of those communities from which I derive my identity" (MacIntyre, 1985, p. 221). But which versions of which stories? This point is nicely brought out by a question asked of Ricoeur in Ireland. The questioner points out that "the problem of retelling the narrative is that it is told and retold so that you get not one agreed narrative but two narratives, and the competing narratives simply duplicate the conflicting ideologies from which they come. How, in this country, can you get a shared narrative about identity?" (Kearney (ed.), 2004, p. 46).

${ }^{88}$ Turner, 2001, p. 43.

${ }^{89}$ Ibid., especially p. 54. For Turner, such self-deception is manifested by Judge William, who "has been carried away with his own story about himself" (ibid., p. 51). Though his expressed aim in his first letter to A is to save the "aesthetic validity" of marriage, Turner argues that Judge William preserves the aesthetic in everyday life only "by offering an overly beautiful account of that life" (ibid.). For instance, he seems inadequately aware of the potential vulnerability of a marriage (including his own), his attitude towards it being "one of complete confidence" (ibid., p. 50). He fails to scrutinize his assumption that his marriage is "the ethical (and aesthetic) norm" (ibid., p. 53). It is worth noting that when in Dependent Rational Animals MacIntyre 
criticizes his own earlier position (from After Virtue to Three Rival Versions of Moral Inquiry), one of the things for which he takes himself to task is precisely this downplaying of the ethical significance of human vulnerability.

${ }^{90}$ Turner, 2001, p. 54.

${ }^{91}$ Ibid., emphasis in original.

${ }^{92}$ Cf. Currie, 1998, p. 656. Note in particular that some of the most marvellous novels are narratives of self-deception, Tolstoy's Anna Karenina and Nabakov's Lolita being two of the most obvious examples.

${ }^{93}$ This point is nicely captured by Adam Morton, in an imagined dialogue between a woman who thinks she "sees herself" in Anna Karenina, and a friend of hers, who says: "Beware stories. I mean, look out for the ways they supply you with prepackaged emotions to make a nice self-portrait. So you should be suspicious of the pressure to see your life as a story. You find yourself supplying tidy endings and pleasing connections between events. You insert irony, suspense, tragedy, and justice. ... If I can do anything for you in this conversation it is to convince you that you don't have to put this particular frame around your situation. There are lots of ways you can see it. For the better ones you'll have to step back from your present emotion a bit, to escape the story it's forcing you into.” (Morton, 2002, pp. 55-6)

${ }^{94}$ Collingwood, 1938, p. 218.

${ }^{95}$ In his discussion of "narrative unity", John Davenport gives a central role to "earnestness", which he claims Kierkegaard regards as "the basic proto-virtue of the will” (Davenport, 2001b, p. 277), akin to phronesis in Aristotle or constancy in MacIntyre's Jane Austen: that without which the other virtues pretty much lose their point (ibid., pp. 277-282). But Davenport's account rests to an important degree on a connection between Kierkegaardian choice and Harry Frankfurt's notion of volitional 
identification, an issue which I shall address in the next section. For a critique of Davenport on earnestness, see Lippitt (2005).

${ }^{96}$ Kierkegaard, 1843/1987b, p. 198.

${ }^{97}$ Kierkegaard, 1850/1990, p. 44.

${ }^{98}$ See Kierkegaard (1847/1993).

${ }^{99}$ It is not always clear to what the term "the eternal" refers in Purity of Heart. But whatever the referent, the privileged place given to the eternal over the temporal is made clear in passages such as the following:

"To take one's suffering to heart is to die to temporality and sagacity and evasions, and to the sagacious men and women, and to anecdotes about this one and that onein order to find rest in the blessed trustworthiness of the eternal. The sufferer can be compared to a sick person who turns from side to side and finally finds the position in which there is relief - even though the wish pains. Even if it were a trifle, one can never have taken something too much to heart if one took it in such a way that one gained the eternal.

But the sufferer who does not wish to be healed by the eternal is doubleminded ... The double-minded person wills to be healed and yet does not will to be healed - that is, he does not will to be healed eternally. But the temporal healing is uncertain ... Alas, for the person who loves the world in the sagacious sense of the moment, the eternal is a riddle. He is continually thinking: But if some temporal help suddenly turned up, I would indeed be deceived, I who in the decision of eternity was dead to temporality. This means that one still regards the temporal as the highest and the eternal as a kind of desperate standby. Therefore one postpones the decision as long as possible; and even if temporality's help is the most unreasonable of all expectations, goaded on in superstitious delusion one would rather hope for it than 
grasp the eternal. There is the continual fear that one would come to regret this, and yet the eternal, if one grasps it in truth, is the only, unconditionally the only thing of which one may unconditionally say: It is never regretted.” (ibid., pp. 113-114)

${ }^{100}$ Ibid., p. 34.

${ }^{101}$ Ibid.

${ }^{102}$ Walker, 1972, pp. 125-126.

${ }^{103}$ Quinn, 2001, p. 330.

${ }^{104}$ Ibid., my emphasis.

${ }^{105}$ See Diamond (1991).

${ }^{106}$ Quinn, 2001, p. 333.

${ }^{107}$ Davenport and Rudd, 2001, p. xxxi.

${ }^{108}$ Davenport (2001a), (2001b). See especially Davenport, 2001a, pp. 84ff.

${ }^{109}$ See Frankfurt (1999).

${ }^{110}$ Ibid., p. 99.

${ }^{111}$ See Frankfurt (1988).

${ }^{112}$ Frankfurt, 1999, p. 99. Such indecisiveness, Frankfurt claims, is as irrational as holding contradictory beliefs (ibid.).

${ }^{113}$ Ibid., p. 100.

${ }^{114}$ Davenport, 2001b, p. 293.

${ }^{115}$ Ibid., my emphasis.

${ }^{116}$ Frankfurt, 1999, p. 99.

${ }^{117}$ Ibid.

${ }^{118}$ Note, too, that owing to lack of space, I have only been able to sketch these examples quite schematically. Yet really to get to the bottom of any such example might require a far greater level of detail - perhaps that which, as Martha Nussbaum 
has suggested, only something like a novel, rather than a philosopher's example, can provide. See especially Nussbaum (1990a).

${ }^{119}$ Cavell, 1971, p. 145. Relatedly, talk of "life plans" seems to overlook the important truth in John Lennon's words, that "life is just what happens to you while you're busy making (other) plans" ("Beautiful boy (darling boy)" on Lennon Legend: the Very Best of John Lennon).

${ }^{120}$ Quinn, 2001, p. 333. I take it that one can agree with Quinn's general point here without accepting that the Nietzschean terminology necessarily helps.

${ }^{121}$ Davenport, 2001b, p. 320, my emphasis.

${ }^{122}$ I borrow these terms from Jeffrey Blustein. See Blustein, 1991, p. 133.

${ }^{123}$ Ibid.

${ }^{124}$ See Kekes (1983) and Kekes (2002), chapter 1. The term "unconditional" is Kekes'; "identity-conferring” is Lynne McFall's, used to mean essentially the same thing (see McFall (1987)). Both are intended to capture the idea of volitional or practical necessity: the kind of commitment found in Luther's infamous "Here I stand; I can do no other".

${ }^{125}$ Kekes (1983, p. 499) distinguishes between two dimensions of integrity: principled action (or authenticity) and wholeness (or constancy).

${ }^{126}$ Kekes, 1983, p. 515.

${ }^{127}$ Blustein, 1991, p. 134.

${ }^{128}$ Kekes, 2002, p. 19.

${ }^{129}$ Ibid., my emphasis.

${ }^{130}$ Ibid., p. 23.

${ }^{131}$ Ibid., p. 35. 
${ }^{132}$ See Ferreira (1991). Significantly, in his discussion of marriage, Judge William admits that "beautiful, significant interruptions are only sparsely allotted in the humdrum routine of daily life" (Kierkegaard, 1843/1987b, p. 102). Furtak suggests that the Judge "has allowed his earlier emotions to form his character so rigidly that he is no longer open to perceptions of significance" (Furtak, 2005, p. 87).

${ }^{133}$ Lyas, 2002, p. 245.

134 Tolstoy (1960).

${ }^{135}$ Lyas, 2002, p. 247, my emphasis. In his discussion of practical necessity, Blustein suggests that in such moments as Luther faced, "one discovers a fact about oneself, namely, an incapacity in oneself to forbear from a certain course of action" (Blustein, 1991, p. 120). But Lyas enables us to see another possibility. Having said that one couldn't live with oneself if one undertook a certain course of action and yet then succumbed to just this course of action (perhaps after the fashion of Frankfurt's unwilling addict), one might come to see that one can live with oneself after all. ${ }^{136}$ Frankfurt, 1999, p. 106.

${ }^{137}$ Nussbaum, 1990b, p. 138. Nussbaum's view of moral imagination is starkly at odds with that of Kekes, who in a chapter on moral imagination suggests: "Moral wisdom may be understood ... as the character trait that enables us, to the extent that we have been able to develop it, to transform complex moral situations into simple ones ... A deeper understanding of moral wisdom ... leads to seeing it as the capacity for increasing control”' (Kekes, 1995, p. 95).

${ }^{138}$ Cited in Diamond, 1991, p. 313.

${ }^{139}$ Diamond, 1991, p. 314. Diamond derives this from James, who glosses the word adventure thus: “a human, a personal 'adventure' is no a priori, no positive and absolute and inelastic thing, but just a matter of relation and appreciation - a name we 
conveniently give, after the fact, to any passage, to any situation, that has added the sharp taste of uncertainty to a quickened sense of life." (James, 1934, p. 286).

${ }^{140}$ Nussbaum, 1990b, p. 141.

${ }^{141}$ Ibid.

${ }^{142}$ Ibid., p. 132.

${ }^{143}$ Schechtman, 2004, pp. 425-426.

${ }^{144}$ Ibid., p. 426.

145 Ibid.

${ }^{146}$ Diamond, 1991, p. 313. As a good example of what Diamond means by this, consider an example from earlier in her paper: Socrates' treatment in the Crito of the laws of Athens as being those who brought him up, such that he owes more to them than he owes to his biological parents. Diamond points out how certain commentators have overlooked just what a strikingly original picture Socrates offers here. Taking it for granted "that moral thought about a particular case consists of bringing principles and rules to bear on the facts of a case", such a commentator "does not envisage as a possibility that any moral thinking goes on in what one takes to be the facts of a case, how one comes to see them or describe them" (ibid., p. 310).

${ }^{147}$ Cf. Luce Irigaray: "Love can be the becoming which appropriates the other for itself by consuming it, introjecting it into itself, to the point where the other disappears. Or love can be the motor of becoming, allowing both the one and the other to grow. ... Two lives should embrace and fertilise each other, without either being a fixed goal for the other" (Irigaray, 1992, p. 27). Isn't thinking of my love life in terms of my "goals" or "life plan" to flirt dangerously with the former?

${ }^{148}$ Of course, love is not the only way in which this can happen. Another serious contender is being brought up against one's own mortality. Again, consider the case 
of Ivan Ilyich: his life has a "narrative unity" of sorts, but on his death-bed, he comes to see that the way he has lived his life has been a terrible mistake; his life has been committed to completely the wrong values. Tolstoy clearly implies that with this realisation - which amounts to the shattering of whatever "narrative unity" his life has possessed - comes Ivan's salvation.

${ }^{149}$ Earlier versions of this paper were presented at the Universities of Hertfordshire and Warwick, St Olaf College and as the keynote address to the Søren Kierkegaard Society of the USA at the American Philosophical Association's Eastern Division meeting in Boston (in December 2004). I am grateful to Christine Battersby, Jeanine Grenberg and John Davenport for invitations to speak on these occasions. Some of the material was also presented and discussed in seminars at Westmont College and Northern Arizona University. I am grateful to my audiences in each case, and to others who have discussed these matters with me either in person or by e-mail, especially John Davenport, Peter Lamarque and Anthony Rudd. I would also like to thank the Kierkegaard House Foundation and the British Academy for the grants that enabled me to pursue this research; the University of Hertfordshire for time off from teaching and administration duties; and the Hong Kierkegaard Library at St Olaf College for providing such a pleasant environment in which to work during my period of research leave. Finally, I would like to thank the two anonymous referees for Inquiry for their very useful comments on the penultimate draft of this article. 